Review on Agriculture and Rural Development 2019 vol. 8 (1-2) ISSN $2677-0792$

\title{
THE IMPORTANCE OF SOCIAL CAPITAL IN AGRICULTURE
}

\section{TIBOR BENCZE}

\author{
Szent István University, Doctoral School of Management and Business Administration, \\ Gödöllö, Hungary \\ bence.tibee@gmail.com
}

\begin{abstract}
The concept of social capital became known in the 1980's as an immaterial resource in the society and it is also a popular area of sociological and economic researches nowadays. Bourdieu, Coleman, and Putnam created the fundamental conceptions of the social capital. Defining social capital as capital involves the philosophy of serving as a resource for the social network.

Studies of the rapidly growing economy of East Asia always emphasize the importance of dense social networks. These networks, the unacceptable, the confidential, reduce the transaction costs, speed up the flow of information and innovation. Social capital and financial capital can be converted. The great economic developments in Hungarians in the last century are different from these causes. In Hungary, there is a very low level of cooperation as well as willingness to develop it. Among Western European countries the level of trust is lower than the average. This basic problem is closely related to the low level of trust and social capital in society as a whole. Partnerships and cooperations are essential nowadays as they can be beneficial to the whole society and economy. In addition, the farmers' eagerness to associate is also weak and the options on how to resolve this issue are still not settled.

Enforcement of the Hungarian peasantry in agricultural cooperatives (1958-1962) left a profound impression on society and its consequences must be taken into account. The good reputation and the credit could be quickly lost; on the contrary recovery - especially rebuild mutual trust- takes more time. Hungarian farmers do not have the confidence to regain each other in the long run. It should be changed, otherwise the majority of the Hungarian farmers will not have the chance to stay competitive.
\end{abstract}

Keywords: agriculture, economy, social capital

\section{INTRODUCTION}

The concept of social funds became known in the 1980s, and as a non-material resource in society, is nowadays a popular area for sociological and economic research. There are many definitions of social funds, but in each of them it is common to interpret social funds in connection with networks. Networks are those separable elements that have some connection between them. So, it is a resource that influences the social and economic processes of communities of different social levels (family, neighbourhood, settlement, micro-region, country). Social funds are slowly recognized as a vital component of economic development worldwide. Research results of rural development students show that an effective network of local associations can be at least as important for growth, as physical investment and the right technology. The role of the family is dual, which can help, but at the same time slows down the development, dynamic development and competitiveness of networks.

I took the views of the three most important experts (Bourdieu, Coleman and Putnam) to clarify the concept of social fund.

According to Pierre Bourdieu, there are three basic forms of fund: economic, cultural and social fund. Social fund is created from social obligations or relationships, which can be converted into economic capital under certain conditions. Bourdieu also says that social 
fund is a set of current and potential resources that are linked to a lasting network of relationships that are more or less institutionalized based on mutual acquaintance and recognition. (BOURDIEU, 1998).

James S. Coleman regards social structural resources as the fund of individuals, i.e. social fund. Social fund is determined by Coleman's function. The concept of social fund defines the function of the resource as a resource for the actors of the social structure that they can use to enforce their interests (COLEMAN, 1994).

According to Robert D. Putnam, the concept of social fund refers to social networks and standards of reciprocity, the basic idea being that social networks have value. Accordingly, social networks can be a significant resource for individuals and groups and communities. Social fund is typically composed of bonds, norms and trust that can be transferred from one social environment to another. (PUTMAN, 1993)

The reason for the different interpretations of social fund is explained by the fact that different authors examine the area from a different perspective. Four main approaches are distinguished (WOLZ ET AL., 2004): the area covered, the manifestation, the benefits obtained and the thoughts of the relationship. Several authors also try to define the expression approach. In Stulhofer's work, he depicts the social fund structure as follows (Figure 1):

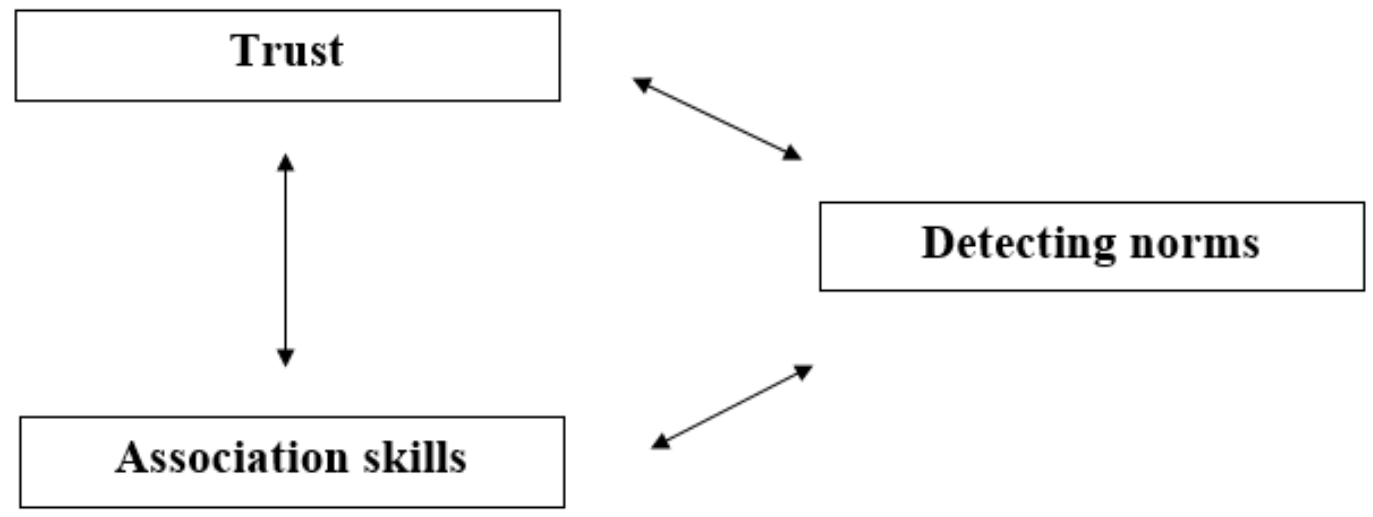

Figure 1.: The structure of social capital Source: STULHOFER, 2000

The delineation in Figure 1. has long been a question which precedes the other. However, the figure lacks an element, and that is honesty. I think this is the first step in strengthening social capital.

Before the examination I had the following hypotheses:

1. The farmers I interviewed have been affiliated with over $50 \%$ at some level.

2. Farmers under the age of 40 would be willing to enter the partnership above 50 percent. 


\section{MATERIAL AND METHOD}

Studies of the rapidly growing economy of East Asia have always emphasized the importance of dense social networks. These networks, which are often made up of a wider family circle or close ethnic community, promote trust, reduce transaction costs, and speed up information flow and innovation. Social fund can therefore be converted into financial fund. China's enormous economic development over the past century can also be attributed to these reasons (VARGA, 1998). This is the central problem of development. If the primary cause of poverty lies in the shortcomings of these three factors, poverty can be mitigated primarily by overcoming these shortcomings. Social fund plays an increasingly important role in the development of developed Western economies. The unexpected decline of free time is a complicating factor, as the members of our generation come into contact with each other to a lesser extent than the market and thus work together less. Families can afford it less, to participate in other social groups other than their workplace, because of the lack of time.

Despite many economic and non-economic benefits, only a small number of producer organizations exist in the Hungarian food industry, their organization and market share are very low, and in general there is a very low level of cooperation and willingness to cooperate in our country. In general, the level of trust in Hungary is lower than the average for Western European countries. The basic problem mentioned above is closely related to the low level of trust and social fund, that characterizes society as a whole. Partnership and co-operation are important nowadays, as its results can benefit the whole society and economy.

In Stulhofer's model, trust, norms and association susceptibility form a closely related, back-and-forth system. There is a low degree of association susceptibility among farmers. Even among the vegetable and fruit producers, the opinion is that "if we have to, then we will be associated". The reason behind this behaviour is a very high level of lack of trust, the causes of which, unfortunately, I can only infer. Farmers are unequivocally common in their processing and commercial vulnerability. Nowadays it is said in many forums that farmers' association susceptibility is weak, but the reasons and especially the ways of solving are hardly mentioned.

In connection with the study of social capital, I contacted hundreds of farmers to get a more accurate picture of the subject. During the research I used a questionnaire method. The results are presented in the next section.

\section{RESULTS}

Forcing the Hungarian peasantry into agricultural cooperatives (1958-1962) left such a profound impression on society, that the consequences must be taken into account today. There is truth in it, but only partial truth, because only those older people over the age of 60 remember this experience. The lack of association capacity of younger age groups socialized in producer cooperatives and in different sectors of the public sector is basically not the result of the experiences of the decades between 1960 and 1990. The consequence 
of the socio-economic processes that have occurred with the change of regime is the disruption of mutual trust, which forms the basis of social relations.

In connection with the compensation and privatization, the state-owned state and production co-operative property was divided, where a few did much and the majority was little or nothing. The villagers and the inhabitants of small and medium-sized towns know exactly what their human and professional strengths and weaknesses were of their colleagues, acquaintances or relatives. They also know who has enriched it and how it has come to the periphery of society. They saw who and how "privatized" the profitable complementary activities from agricultural large farms. As a result of the above, it has to be said that people have every reason to distrust each other. The basic human trait is that I only associate whom I do not trust when it is absolute necessary, but then I will only commit to it until it is absolutely necessary.

Old Truth: Good reputation and the trust that underlies it can quickly be lost, grounded, and especially recovered for much longer. However, Hungarian farmers do not have a long time to regain their trust in each other. You have to change this, otherwise the vast majority of Hungarian farmers will not have the chance to stay in competition.

I do not necessarily mean a co-operative formation here during the co-operation. In addition to primary cooperatives (cooperative, TÉSZ, BÉSZ), secondary co-operative and integration organizations, which are the same as the previous ones, need to be established for the purpose of ensuring sufficient interest.

The food chain sare also pushing food processors, trying to apply the ancient principle of "the enemy of my enemy", that is, it is appropriate to link strategic processors with food processors.

During my research, I visited hundreds of farmers to gain more insight into the topic. They are interested in their views on partnership and trust between farmers. During the survey, I also met younger and older farmers to take into account the views of both age groups. I set up two age groups: farmers under 40 and over 40. One of my important questions during my investigation is whether they have been associated with other organizations or farmers over the years (Figure 2.).

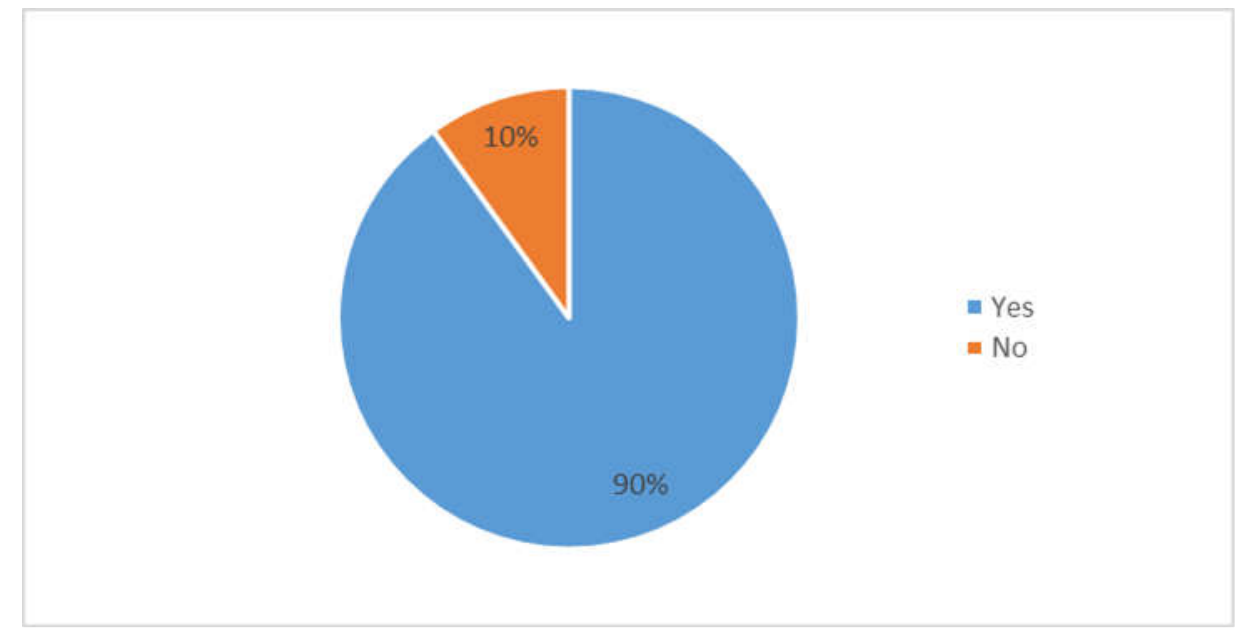

Figure 2.: Collaboration

Source: Based on questionnaire survey, 2019 
It can be seen that $90 \%$ of the farmers surveyed are already affiliated at some level. I was interested in what kind of problems were the most typical. The most mentioned problems were the distribution of finances and organizational problems. During the organizational problems, everyone wanted to start with their own when using a new technology, which caused problems. $15 \%$ of the farmers surveyed are still in some kind of partnership right now.

In the next section I have already split the respondents according to whether they would be associated today.

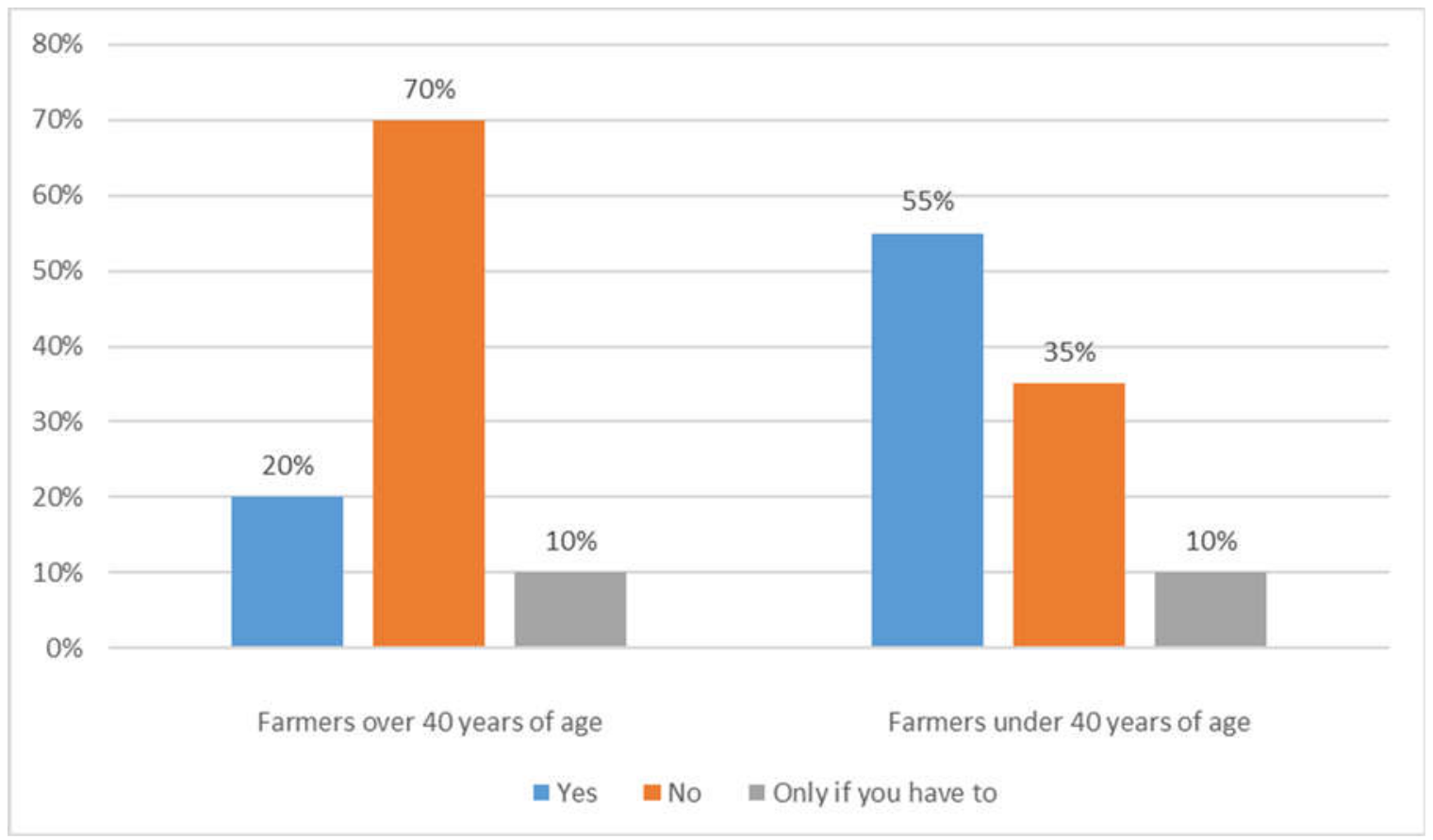

Figure 3. Willingness to cooperate based on questionnaire survey, 2019

The figure shows that $70 \%$ of farmers over the age of 40 do not want to become a partner at all. These farmers are likely to have come out of an association with a negative experience and do not want it again. In this age group, the propensity to associate is seen to be low because 20 percent would be willing and 10 percent only if there was no other choice.

In the younger age group, these data developed differently, as can be seen in Figure 3. It can be seen that the younger generation would associate much more with the older age group. In my opinion, if they had a partnership experience then it was positive, but they have a fear of association. In my experience, the younger age group is more capable of accepting the compulsion to associate than the older ones. Older people are more afraid of innovations, they think they are fine as they are.

The positive benefits of this cooperation for farmers would be: security of sales, price predictability and improved market bargaining power.

The low level of willingness to cooperate is a barrier to increasing production efficiency and increasing employment. 


\section{CONCLUSIONS}

The starting point of the development process is that the involvement of communities in the field of rural and economic development should produce results; However, for these skills to really contribute to modernization processes, it is indispensable to consider work as a priority for community development professionals. The knowledge gained from studying foreign and Hungarian literature has drawn my attention to the importance of strengthening social fund. The data available, as well as my own experience, clearly show that this is a crucial factor in the analysis of the future of the rural economy, which has become increasingly important since the nineties, as well. It is a very difficult question how and at what pace we can achieve a positive change in this area, because the characteristic of social capital is that it can be destroyed in a short time, but its construction is usually the result of a long process. Social fund is interpreted in the report of trust, respect for norms and association susceptibility, and I think that the greatest emphasis is currently placed on strengthening this factor in Hungary. Although financial resources play an important role here, it is important to note that with the strengthening of social fund, social costs would be significantly reduced. Strengthening human fund is also indispensable for building social fund. Education has a significant role to play in creating a mentally and morally trained society.

Both of my hypotheses were correct, because $90 \%$ of the farmers surveyed were already associated at some level, which is good from this point of view. Unfortunately, the need for association is weak in the $40+$ age group, but the $55 \%$ is not very strong in the $40 \mathrm{~s}$.

Some farmers have realized that they can only be successful, viable in the long term and potentially competitive. The main problem facing the agricultural sectors is that production and processing are separated and this can be changed through cooperation between producers. It is important for farmers to recognize that being a member of a producer partnership is not a risk but a safety issue. In a capital-intensive agriculture, often with sales challenges, cooperation can be the basis for stable profitability.

Hungarian farmers are reluctant to pay for expert advice, and they only try to cooperate, but they basically do not trust anyone, which hinders the more efficient production of Hungarian farmers. Due to a lack of trust, farmers are afraid that if they put that particular amount into development, for example, then the other party will also contribute or use questions about who will use it sooner or what the order will be based on. Taking advantage of technological innovations, the association would be in great need so that together they could more easily buy state-of-the-art technology to produce more and better quality. This process can be seen in the following figure (Figure 4.).

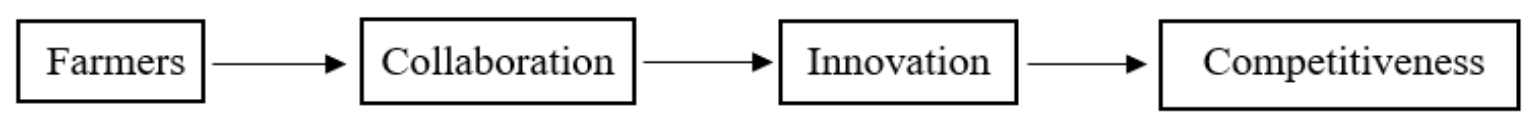

Figure 4. cooperation process 
The partnership would also be of great importance to the problem of employment, because farmers could work together to better solve labor shortages. By working together, farmers would receive useful information from each other and, if they sold their crops together, would be in a better bargaining position with buyers or processors, thus improving their sales opportunities. In my opinion, a very, very long-term cooperative can come together, but in Hungary, I still see, where there are so many private owners, that they are frightened by the word cooperative. If they have a positive example, I think they will be more open to cooperation.

The willingness of young farmers to cooperate is stronger because the old bad habits and experiences do not exist. The new generation may also tend to develop long-term partnerships. Young farmers are less distrustful when cooperating with other farmers than older ones, as shown in the Figure 3. Young people do not shy away from cooperation if they see new opportunities. Among the difficulties it is worth mentioning the fragmented ownership structure, the exodus from the sector, the aging of the agricultural society and the negative feelings of the cooperative period, which hinder the development of cooperation.

\section{REFERENCES}

BourdiEU, P. (1998): Gazdasági tőke, kulturális tőke, társadalmi tőke. In: Tőkefajták: A társadalmi és kulturális erőforrások szociológiája. Aula Kiadó, Budapest.

Coleman, J. S. (1994): Társadalmi tőke. A gazdasági élet szociológiája. Budapest: AULA KIS K. (2006): Partnerség és társadalmi tőke a vidékfejlesztésben, Parola Archívum Putman, R.D. (1993): Making Democracy Work: Civic Tradition in Modern Italy. Princeton. Princeton University Press.

SzABÓ, G., G.-KISS A. (2003): A Termelő Értékesítő Szervezeteknek (a TÉSZ-ek) gazdasági szabályozása az Európai Unióban és Magyarországon. Európai Fórum.

VArga, A. T., Vercseg, I (1998): Közösségfejlesztés. Magyar Művelődési Intézet, Budapest,

Wolz, A., Fiege, U., Reinsberg, K. (2004): The Role of Social Capital in Promoting Institutional Changes in Transitional Agriculture. In: Role of Institutions in Rural Policies and Agricultural Markets. (Eds.: Van Huylenbroeck G., Verbeke W. and Lauwers L.) 